\title{
₹USGS
}

\section{Landslides Triggered By Hurricane Mitch In Tegucigalpa, Honduras}

By Edwin L. Harp, Mario Castañeda, and Matthew D. Held

Open-File Report 02-33

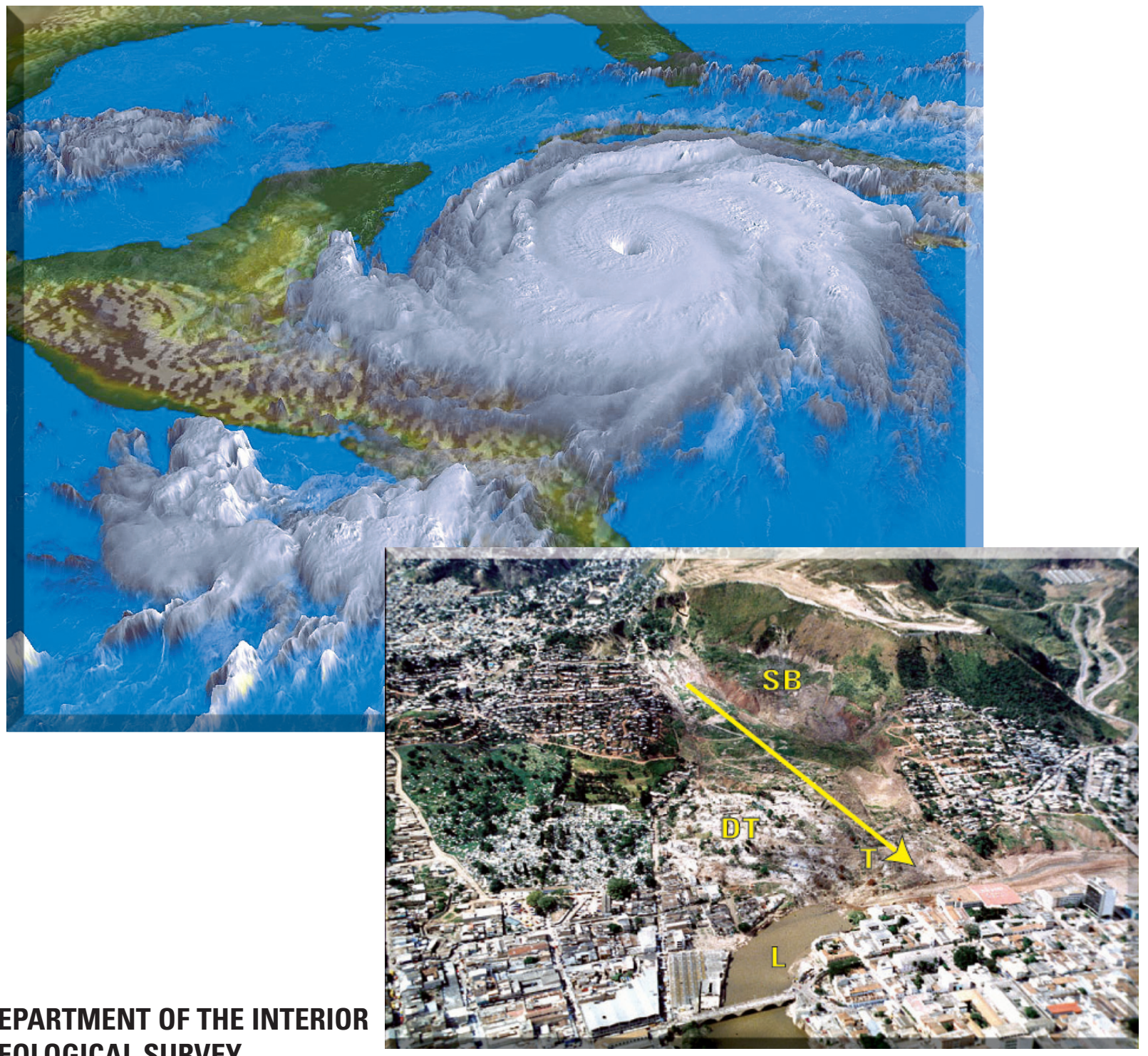

U.S. DEPARTMENT OF THE INTERIOR U.S. GEOLOGICAL SURVEY 


\title{
Landslides Triggered By Hurricane Mitch In Tegucigalpa, Honduras
}

By Edwin L. Harp1, Mario Castañeda2, and Matthew D. Held1

\section{Open-File Report 02-33}

(English version; Spanish version is also available)

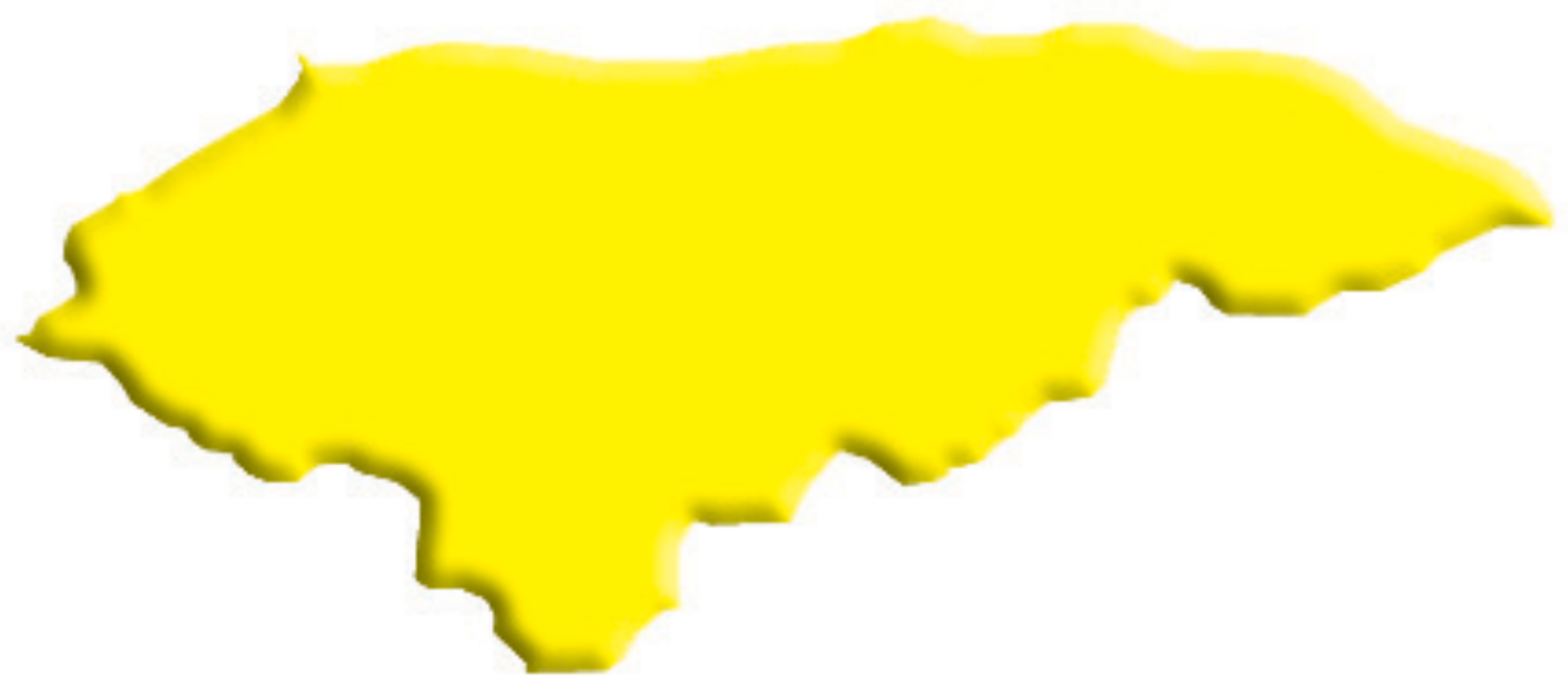

This report is preliminary and has not been reviewed for conformity with U.S. Geological Survey editorial standards or with the North American Stratigraphic Code. Any use of trade, firm, or product names is for descriptive purposes only and does not imply endorsement by the U.S. Government.

\section{U.S. DEPARTMENT OF THE INTERIOR \\ U.S. GEOLOGICAL SURVEY}

\author{
${ }^{1}$ USGS, Denver, Colorado \\ 2Universidad Tecnologica Centroamericana (UNITEC), Honduras
}




\section{Contents}

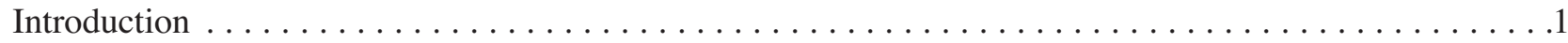

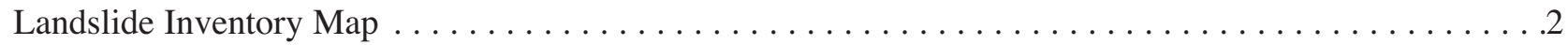

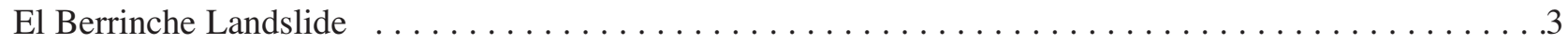

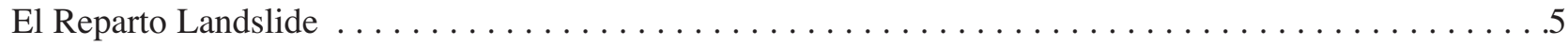

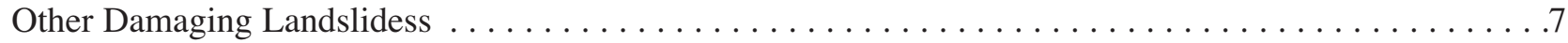

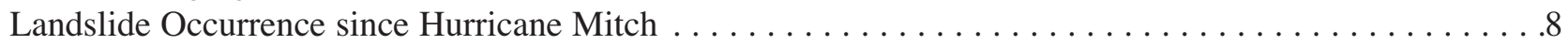

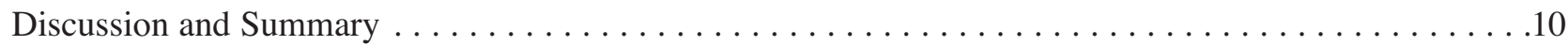

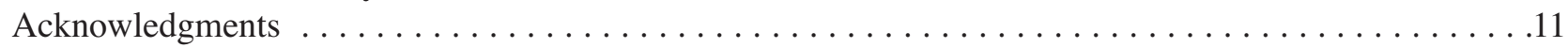

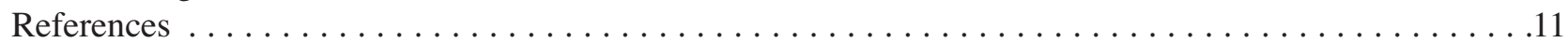

\section{Illustrations}

Figure

1 Map of Honduras

2 Aerial view of the El Berrinche landslide

3 View of the highly deformed toe area of the El Berrinche landslide that destroyed Colonia Soto

4 View of the El Berrinche landslide looking obliquely downslope

5 Aerial view of the El Reparto slump/debris flow

6 Headscarp area of El Reparto landslide showing small pond

7 Debris slide at Barrio Mira Mesi adjacent to the Rio Choluteca

8 Debris slide at Barrio Mira Mesi that has progressed headward even during dry seasons following Hurricane Mitch

9 Debris slide along the Río Guacerique

10 Reactivated rotational slump in Barrio Santa Rosa

11 Toe of slump in neighborhood of Campo Cielo in Tegucigalpa

Plate 1 [in pocket]

Landslides triggered by Hurricane Mitch in Tegucigalpa, Honduras

Hurricane Mitch approaching Central America on 26

The hurricane is over the north-

The image is derived from satellite data -enhanced and processed to yield a perspective rendering Atmospheres, NASA Goddard Space Flight Center.

Tegucigalpa 


\title{
Landslides Triggered By Hurricane Mitch In Tegucigalpa, Honduras
}

\author{
By Edwin L. Harp, Mario Castañeda, and Matthew D. Held
}

Abstract: Torrential rainfall from Hurricane Mitch triggered several hundred landslides within the cities of Tegucigalpa and Comayaguela and the surrounding populated area. Most of the landslides were relatively shallow debris flows; however, the one landslide that had by far the greatest impact on the public was the deep-seated slumplearth flow that occurred below the summit of Cerro El Berrinche. This landslide totally destroyed Colonia Soto and parts of neighboring Colonias Catorce de Febrero and El Porvenir. The landslide, approximately six million cubic meters in volume, also dammed the Rio Choluteca, which created a reservoir of stagnant, sewage-filled water behind the dam. A smaller slump/earth flow of approximately
400,000 $\mathrm{m}^{3}$ volume destroyed several houses in Colonia El Reparto. Two rock and debris slides triggered by erosion of river banks by floodwaters destroyed houses at Barrio Mira Mesi and Nueva Esperanza on the Río Choluteca and Río Guacerique respectively.

Landslides depicted on the map shown in Plate 1 were mapped from 1:40,000-scale aerial photography taken by the U.S. Air Force under "Project Open Skies" and from 1:20,000-scale color aerial photography taken by a private contractor. This landslide inventory provides the basic data for a computerized slope-stability analysis from which a "Landslide Susceptibility" map of the Tegucigalpa area will be produced.

\section{Introduction}

$\mathrm{T}_{\mathrm{s}}^{\mathrm{s} \pi \mathrm{se}}$ he arrival of Hurricane Mitch in Honduras in the latter part of the 1998 hurricane season produced effects that were unprecedented in their widespread nature throughout Central America. After winds from the storm had blown down more than 70 percent of the conifer forest on the Bay Island of Guanaja, the hurricane turned inland and stalled over the mainland of Honduras for 3 days. The resulting deluge of rainfall produced devastating flooding and landslides that resulted in more than 9,000 fatalities and 3 million people displaced. Although the eye of Hurricane Mitch passed through the northern part of Honduras, the greatest rainfall totals and intensities occurred in the southern part of the country near Choluteca. For the three days October 29-31, 1998, total rainfall at Choluteca exceeded $900 \mathrm{~mm}$. Not surprisingly, it was in this area that the highest landslide concentrations occurred.

Rainfall from Hurricane Mitch in the capital city of Tegucigalpa totaled $281 \mathrm{~mm}$; although this is much less than that received at Choluteca, it was more than three times the precipitation received during Huricanes "Gert" and "Fifi" (Servicio Meteorologico Nacional, unpub. Data). In general, landslide patterns in Tegucigalpa were similar to those elsewhere in the country. Most of the landslides were shallow debris flows having average thicknesses of 1-2 m. Runnout distances of the debris flows ranged from several meters to several hundred meters (Plate 1). Although concentrations of debris flows were high in parts of the city, they did not come close to the concentrations of hundreds per square kilometer that was common in the hills near Choluteca in southernmost Honduras.

Landslides other than debris flows were few in number, but they constituted the greatest impact by far on the city and its populace. Two slump/earth flows and two debris slides accounted for a major part of the total landslide damage that occurred in Tegucigalpa. The following text and illustrations describe the landslides, their distribution in Tegucigalpa, and their impact on people and property within the city. 


\section{Landslide Inventory Map}

$\mathrm{T}$ he landslides triggered by Hurricane

Mitch within the city of Tegucigalpa were mapped from a combination of post-hurricane 1:40,000-scale black-and white airphotos taken by the U.S. Air Force under "Project Open Skies" and 1:20,000-scale color airphotos taken by a private contractor. The landslides were interpreted from stereo pairs of the photography and sketched onto 1:10,000scale topographic maps of the city; landslides were later digitized as polygons to form a GIS landslide database. The four $1: 10,000$-scale topographic maps of the city were subsequently mosaicked to form a single map sheet onto which the landslide database was plotted (Plate 1). Landslide terminology used in this report is consistent with that of Varnes (1978) and Cruden and Varnes (1996).

Debris flows and soil slides that mobilized into debris flows outnumbered all other types of landslides triggered in the Tegucigalpa area. A debris flow is a landslide that consists of a fluid mixture of soil and water or soil, rock, and water; debris flows form viscous slurries that flow downslope at velocities that can approach $50 \mathrm{~km} / \mathrm{hr}$. Numerically these comprise more than $95 \%$ of the landslides that occurred. However, the four deeper seated landslides mentioned above accounted for most of the damage to people and property that occurred in the metropolitan area.

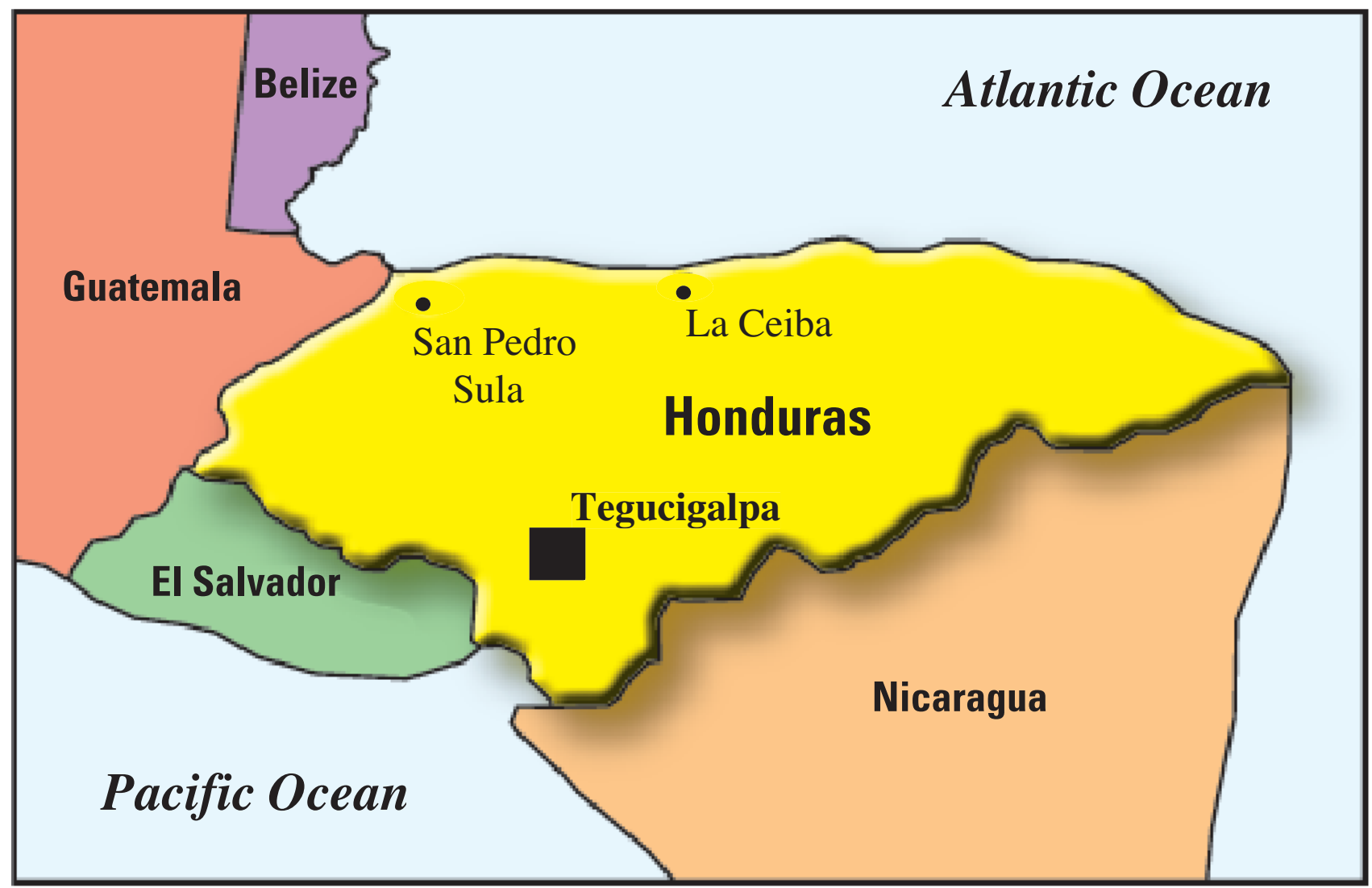

Figure 1. Map of Honduras. Open rectangle denotes area of Plate 1. 


\section{El Berrinche Landslide}

$\mathrm{T}_{\mathrm{h}}^{\mathrm{h}}$ he El Berrinche landslide in Tegucigalpa was the largest single landslide (\#1, Plate 1) triggered by Hurricane Mitch in Honduras. It destroyed a portion of the central part of the city known as Colonia Soto and dammed the Río Choluteca, creating a sewage-filled lagoon upstream from the landslide dam (figure 2). This complex slump/earth flow had a volume of approximately 6 million cubic meters. Because of initial slow movement of the landslide during the hurricane-associated rainfall, city residents living on the landslide mass were evacuated prior to its rapid movement that culminated in the damming of the river. The river was dammed at approximately 12:30 a. m. on October 31 , about one hour after the peak flood flow of the Río Choluteca.
The El Berrinche landslide consists of three basic parts. With reference to figure 2, the part of the landslide marked "DT" is a highly deformed toe that buckled and folded extensively but did not travel across the Río Choluteca. A view of this area soon after the landslide occurred is shown in figure 3 .

Just upslope from the deformed toe is an earth-flow tongue that extends the entire length of the landslide from upper left to lower right. This earth-flow tongue is that part of the slide mass that actually flowed across and dammed the Río Choluteca creating the lagoon. A downslope view of this part of the landslide mass is shown in figure 4.

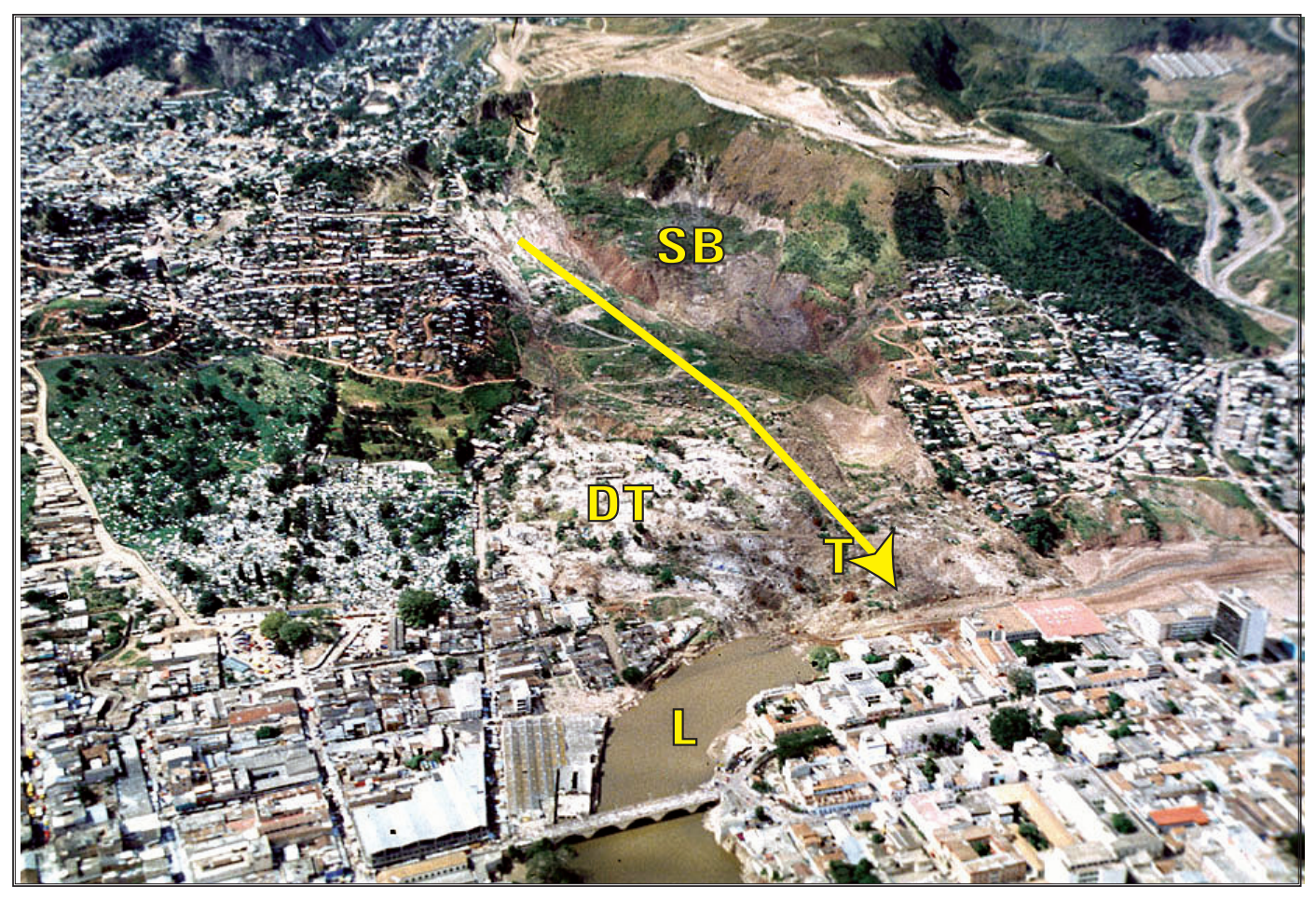

Figure 2. Aerial view of the El Berrinche landslide, a complex slump/earth flow that dammed the Río Choluteca in Tegucigalpa. The arrow indicates the direction of movement of the earth-flow tongue. " $T$ " denotes the toe of the landslide that dammed the river, and "L" indicates the lagoon dammed by the toe of the landslide. "DT" indicates the highly deformed toe of the landslide where the center of Colonia Soto was, and "SB" denotes the upper slump block. 
Figure 3. View of the highly

deformed toe area of the El Berrinche landslide that destroyed Colonia Soto. The view here is of the remains of Colonia Soto as seen in December 1998. The remains of houses and streets can be seen rotated at high angles from horizontal.
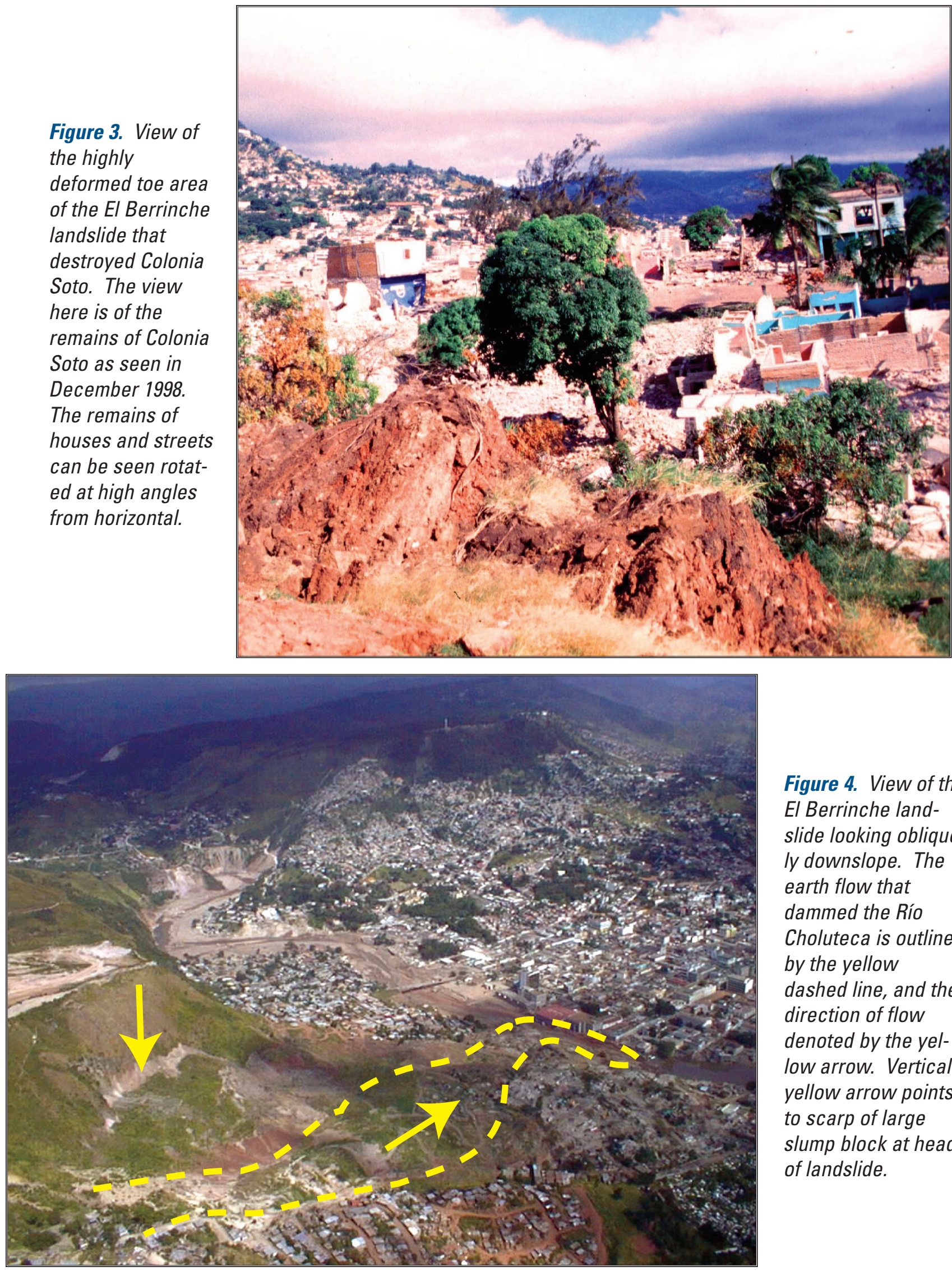

Figure 4. View of the El Berrinche landslide looking obliquely downslope. The earth flow that dammed the Río Choluteca is outlined by the yellow dashed line, and the direction of flow denoted by the yellow arrow. Vertical yellow arrow points to scarp of large slump block at head of landslide. 
Just to the left and upslope from the earth flow in figure 4 (denoted by a vertical arrow) is the third main portion of the landslide, a slump block shown as "SB" in figure 2. This slump block has a scarp approximately $30 \mathrm{~m}$ high at its upslope margin. This scarp appears to be a contact between deeply weathered deposits of clay and silt derived from rhyolitic volcanics that contain interspersed conglomerate and hard, competent, rhyolitic ignimbrite exposed above the scarp.

The damming of the Río Choluteca by the landslide and the creation of the lagoon upstream from the landslide dam also created a significant health hazard to the people who lived in the downtown area near the river. In early December 1998, dredging by construction crews from Mexico proved to be insufficient to cut a deep enough channel to drain the lagoon. With the drainage of the lagoon a high priority of the city of Tegucigalpa and the government of Honduras, the U.S. Army Corps of Engineers and the U.S. Geological Survey were asked, on an emergency basis and with no time to complete a systematic study, to evaluate the stability of the landslide mass near the toe should a deeper channel be excavated through the landslide dam. With the proposed channel design from local engineers, geologists from the U.S. Army
Corps of Engineers and the U.S. Geological Survey considered the proposed shape and dimensions of the landslide toe once the channel had been excavated and concluded that the toe would be stable except for small localized slumping of the toe as the river eroded material from the toe during the drainage of the lagoon. This decision, based mainly on experience and judgement and without the aid of borings, samples, or any preliminary stability analysis, proved to be correct, and the landslide toe has remained relatively stable since the lagoon was drained.

Since the initial draining of the lagoon, a slope stability analysis has been performed by the U.S. Army Corps of Engineers, and most of the landslide mass has been regraded and contoured to enhance the stability and drainage of the slide mass. Both rainy seasons since Hurricane Mitch have produced lower than normal cumulative rainfall, and the El Berrinche landslide has remained stable except for localized slumping within the lowest part of the landslide toe where steeper slopes have been produced by channel excavation. A more rigorous test of the landslide's stability will occur when a future rainfall season exceeds normal rainfall totals.

\section{El Reparto Landslide}

\footnotetext{
nother deep-seated landslide, a Aslump/debris flow having a volume of $400,000 \mathrm{~m}^{3}$, destroyed numerous houses in the Colonia El Reparto section of Tegucigalpa (\#2, Plate 1; figure 5). This landslide occurred during the midmorning of October 31 over a time span of several hours. The final movement of the slump resulted in the formation of a debris flow, which mobilized from the oversteepened toe of the landslide and demolished the houses. Because of the
}

initial slow movement of the landslide, all inhabitants of the houses were able to evacuate.

The El Reparto landslide is a reactivated portion of a larger landslide complex. Its headscarp is at the margin of a large downward-rotated block (shown as "RB" in figure 5) of an older landslide complex whose headscarp is the surrounding steep slope forming the skyline in figure 5. 
Figure 5. Aerial view of the El

Reparto

slump/debris flow.

"RB" denotes a

rotational block of

an older landslide

complex whose

headscarp is the

steep slope form-

ing the skyline.

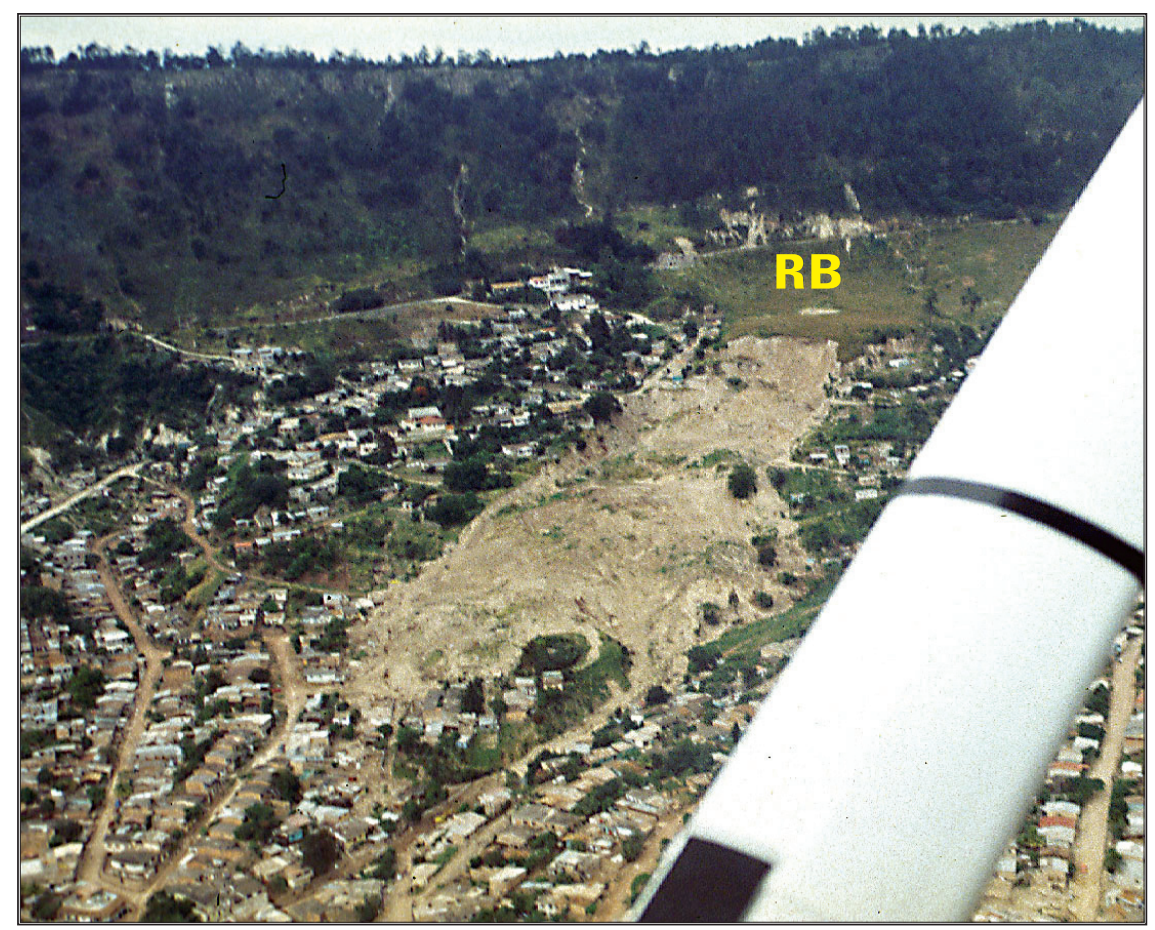

As shown in figure 6, the area below the headscarp of the landslide has a small pond fed by water and sewage lines that were severed by the landslide movement. Recommendations were made to the city to divert flow from these water sources to decrease the water level within the slide mass. These recommendations were subsequently undertaken in November 2000.

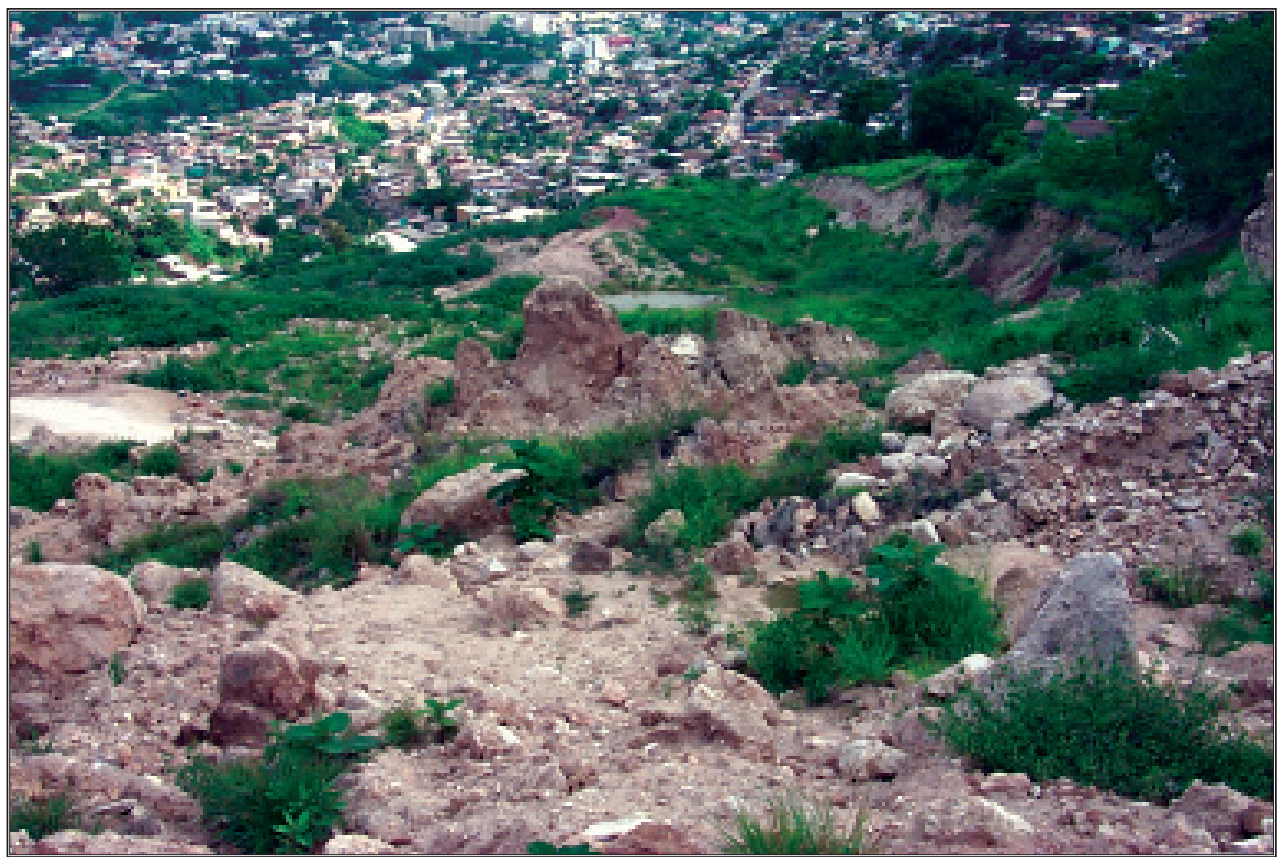

A series of survey points were established on the landslide mass in July 2000; These survey points were resurveyed periodically so that any renewed movement could be detected. This monitoring was undertaken because of all the residences that are still occupied adjacent to and downslope of the landslide.
Figure 6.

Headscarp area of El Reparto landslide showing small pond in right center of photo. 


\section{Other Damaging Landslides}

Ceveral other deep-seated landslides $\checkmark$ caused damage to people and property in the city of Tegucigalpa. Two debris slides triggered by the undercutting of river banks destroyed houses at Barrio Mira Mesi adjacent to the Río Choluteca and at Nueva Esperanza adjacent to the Río Guacerique. The slide at Barrio Mira Mesi (\#3, Plate 1) began as a relatively small debris slide of about 5,000 $\mathrm{m}^{3}$ in older terrace deposits adjacent to the Río Choluteca (figure 7). Several houses were destroyed or damaged by the sliding and subsidence caused by the erosive undercutting of the terrace by the river. The headscarp of this landslide continued to be unstable even during dry seasons of 1999 and 2000 and continued to retrogress upslope and involve additional houses (figure 8).

Figure 7. Debris slide at Barrio Mira Mesi adjacent to the Río Choluteca.
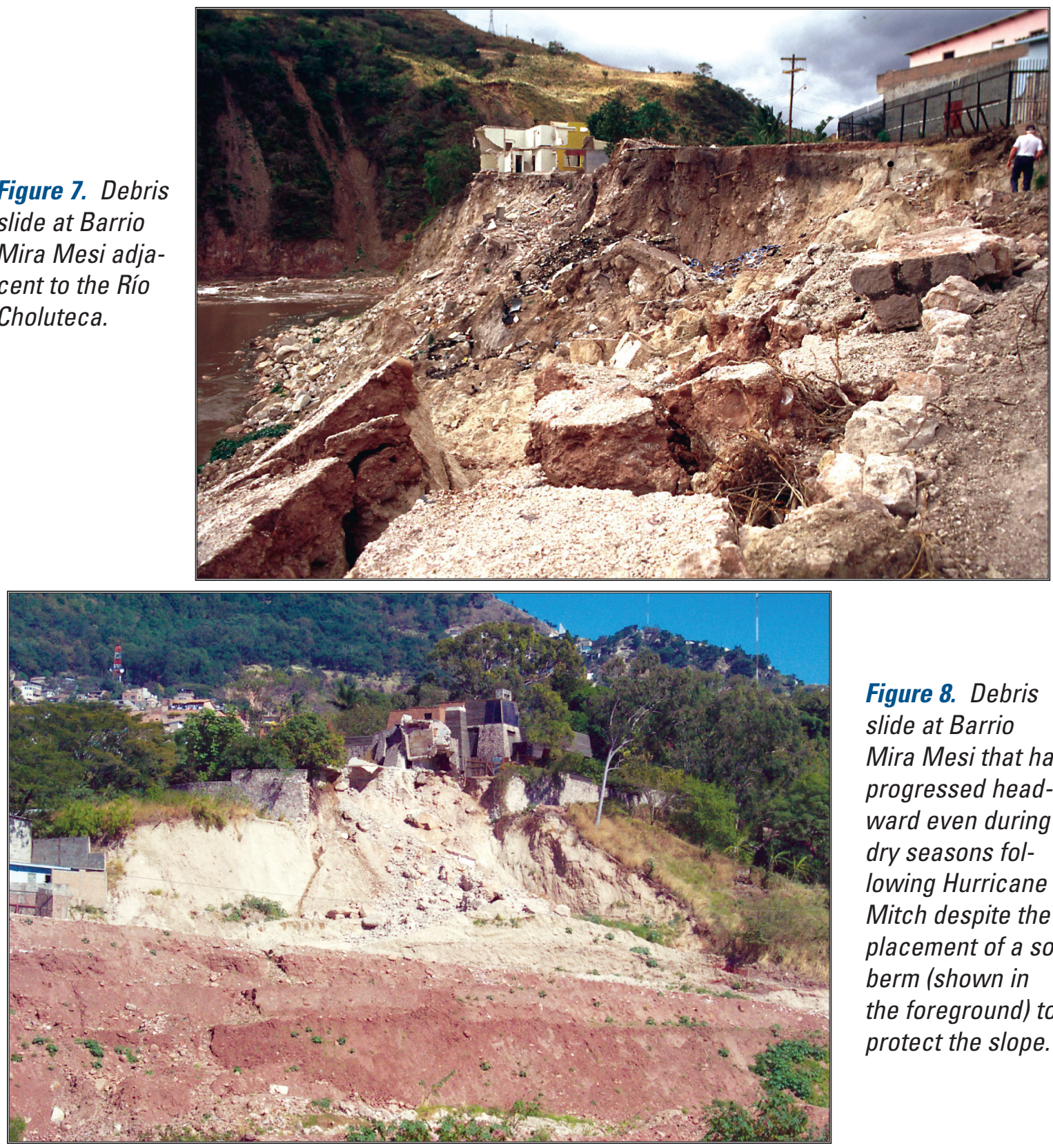

Figure 8. Debris slide at Barrio Mira Mesi that has progressed headward even during dry seasons following Hurricane Mitch despite the placement of a soil berm (shown in the foreground) to protect the slope. 
The debris slide at Nueva Esperanza (\#4, Plate 1; figure 9), triggered by the erosive undercutting of the slope by the Río Guacerique during its peak flow during Hurricane Mitch, destroyed more than 20 homes perched on the steep slopes above the river. As at Mira Mesi, the loose alluvial deposits continued to slide, especially during the rainy seasons following the hurricane; the ongoing sliding destroyed several additional homes.

Figure 9. Debris slide along the Río Guacerique.

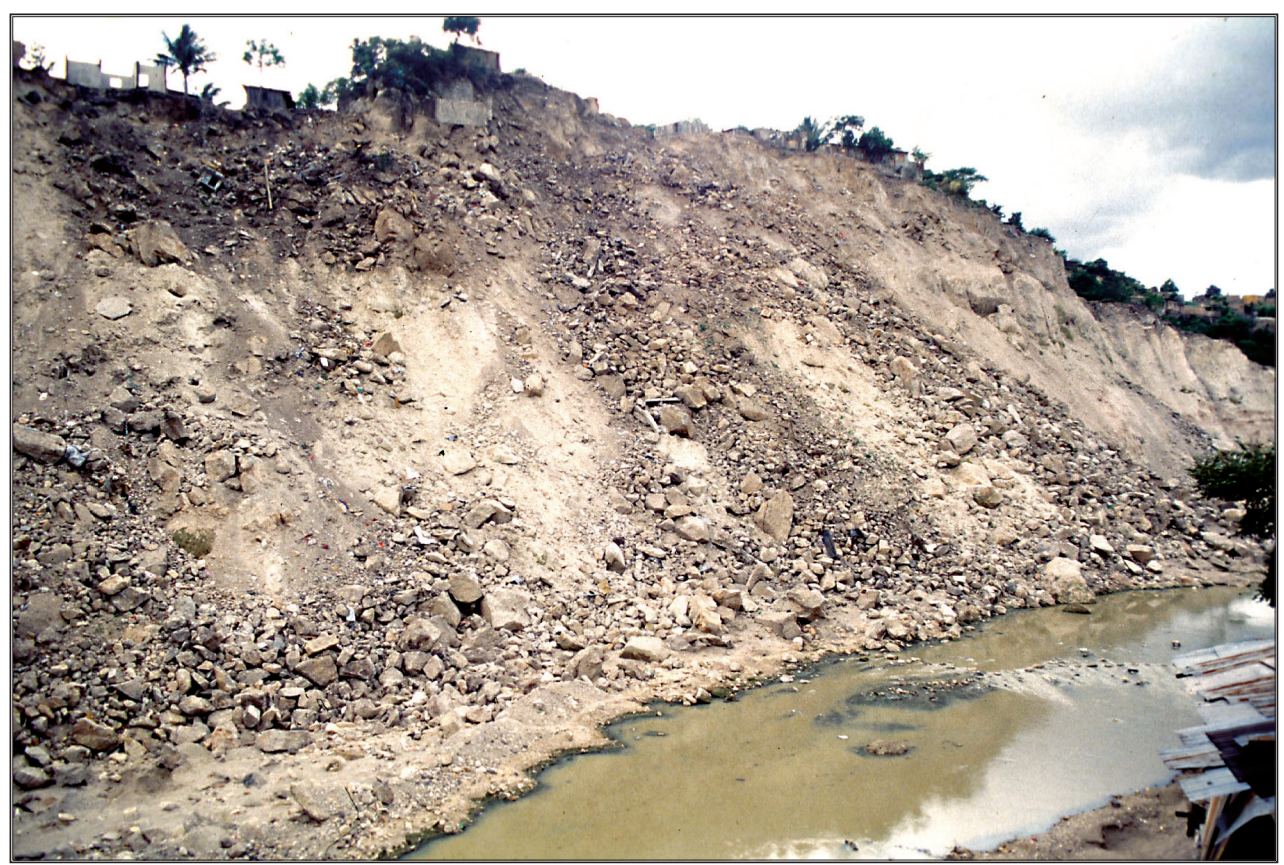

\section{Landslide Occurrence Since Hurricane Mitch}

$\mathrm{D}$ uring the three years since the occurrence of Hurricane Mitch, seasonal rainfall has been average to below average in Tegucigalpa and the surrounding area in the Department of Francisco Morazán. Despite the absence of greater than average seasonal rainfall, a few scattered small debris flows have been triggered by scattered high intensity bursts of rainfall during the rainy season. In addition to these, two moderate-sized slumps have occurred within residential parts of the city.

In Barrio Santa Rosa, 0.5 km southeast of the El Reparto landslide, a slowmoving slump was reactivated in September 1999. An incipient slump that had begun to form during Hurricane Mitch, with about $80 \mathrm{~cm}$ of displacement along a partially formed headscarp underwent renewed movement during a period of intense afternoon rainfall. The reactivated slump involved a volume of about 1,800 $\mathrm{m}^{3}$ and affected 37 homes. This occurred at a time when we were doing field work in Honduras, so we responded to a request from the city to advise them on how many people should be evacuated from the area. The reactivated movement on the headscarp of the slump began on the afternoon of September 23 and totaled about $80 \mathrm{~cm}$ that evening, with another $30 \mathrm{~cm}$ of displacement occurring by the next morning (figure 10). We assessed the situation on the afternoon of the 23rd and recommended evacuation for those homes that were within the limits of the slump. After the end of the intense period of rainfall that afternoon and night, the movement of the slump also terminated. Little, if any, renewed movement has occurred since this episode. 


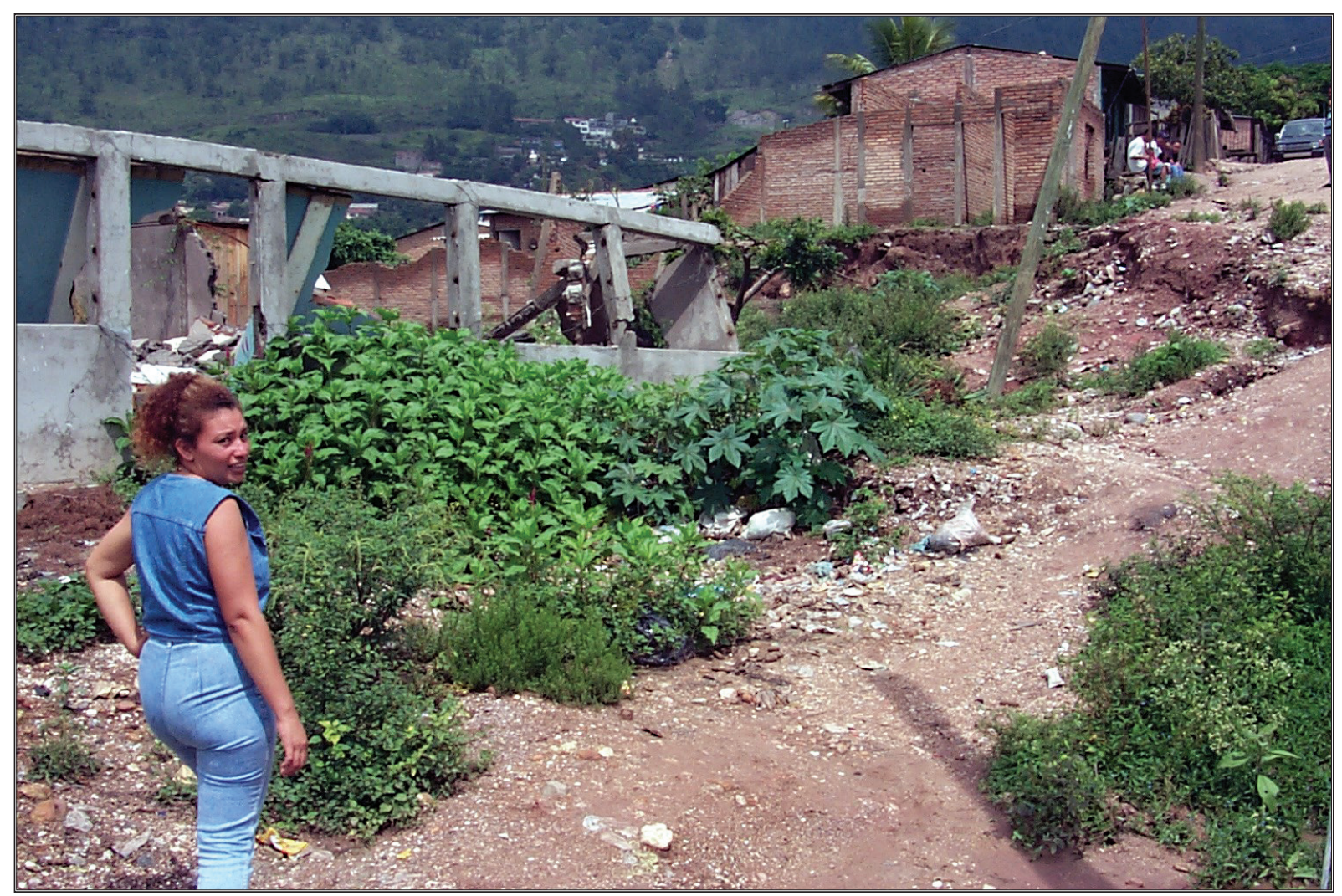

Figure 10. Reactivated slump in Barrio Santa Rosa triggered by intense rainfall in September 1999.

Another moderate-sized slump of about 2,500 $\mathrm{m}^{3}$ occurred about $200 \mathrm{~m}$ south of the El Berrinche landslide in a small neighborhood called Campo Cielo. This landslide began its movement on or about September 23, 1999, on the southeast-facing nose of the ridge just south of the El Berrinche landslide. The initial movement occurred as a scarp about 15 $\mathrm{m}$ long having about $20 \mathrm{~cm}$ of displacement. Once this scarp had formed, little additional displacement occurred at this site, and subsequent slope movement shifted downslope as another headscarp area formed with multiple cracks from which water percolated. The slope below this was saturated to the surface, making foot travel across the landslide almost impossible without sinking into the saturated soil. The toe of this slump was situated behind a row of houses next to a street in the neighborhood. As the slump continued to move at a rate of several centimeters per day over a period of several weeks at the end of the rainy season, the toe grew and eventually made contact with the back walls of the row of houses fronting the street (figure 11). As movement continued, the toe of the slump began squeezing between these houses and breaking through the back walls of the houses. Residents of the houses evacuated the dwellings just prior to the toe of the slump reaching the rear walls.

This area had been the site of recurring spring activity in the rainy seasons of most years. Prior landslide movement of this hillside occurred during Hurricane Gilbert in 1986, when four houses were destroyed and during Hurricane Mitch, when 17 houses were destroyed. During the dry season of 2000 , the city dug trenches through the landslide that are greater than the depth of the slide surface, which is 2-3 m deep. These trenches have succeeded in draining the slide mass and halting movement of the slope. 


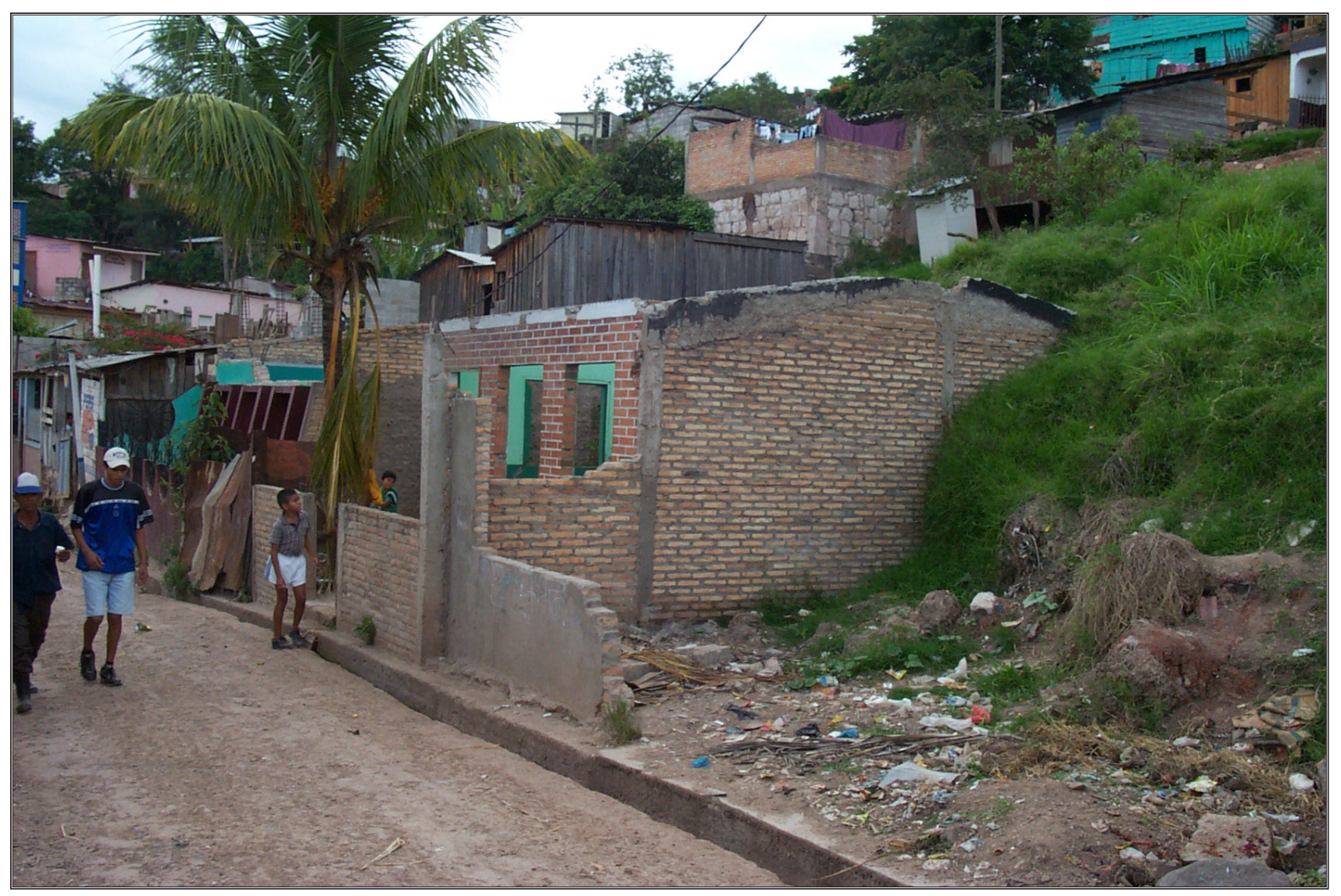

Figure 11. Toe of slump in neighborhood of Campo Cielo in Tegucigalpa. At the right of the photo, the toe of the slide mass is seen impinging against the row of houses.

\section{Discussion and Summary}

$\mathrm{T}$ The inventory of landslides in Tegucigalpa triggered by Hurricane Mitch displayed on Plate 1 consists of over 95 percent debris flows. A few deep-seated landslides occurred within the urban area and are discussed individually in the text. These are indicated on Plate 1 by adjacent numbers corresponding to those listed in the text.

In addition to providing an accurate documentation of the landslides within the city boundaries triggered by Hurricane Mitch for future reference, the landslide inventory map also provides a comparison to an analytical map of Tegucigalpa (Harp and others, 2002) that shows the relative slope stability of the area within the city. This map is known as a landslide susceptibility map and is derived from a GIS-based analysis of the relative slope stability of the same area as the inventory map. Although the distribution of landslides in Tegucigalpa triggered by Hurricane Mitch is technically unique to the rainfall distribution produced by the hurricane, a comparison of the distribution of landslides triggered by Mitch with susceptibility categories from the slope stability analysis does allow a crude assessment of the relative hazard to people and property from landslides triggered by future storms. 


\section{Acknowledgments}

$\mathrm{T}$

The authors would like to acknowledge the assistance of the U.S. Agency for International Development (USAID) and several key individuals whose efforts made the fieldwork, data gathering, and this final report possible. These individuals include: Jeff Phillips of the USGS on temporary duty to USAID as a liaison officer to track all of the USGS effort in Honduras; Adrian Oviedo of USAID who arranged meetings, contacts, and travel for our fieldwork and seminars; and Sherry Thorn, professor of Biology at the University of Honduras who provided translation service, detailed knowledge of all field areas visited in Honduras as well as access to local individuals with eyewitness knowledge of the Hurricane Mitch event, and knowledge of the local customs and practices that proved invaluable for our safety and effectiveness in performing field studies. We greatly appreciate the graphics and layout design by Eleanor M. Omdahl.

\section{References}

Cruden, D. M., and Varnes, D. J., 1996, Landslide types and processes, in Turner, A. K., and Schuster, R. L, eds., Landslides-Investigation and Mitigation: Transportation Research Board Special Report 247, National Academy Press, Washington D. C., p. 36-75.

Harp, Edwin L., Held, Matthew D., Castañeda, Mario, McKenna, Jonathan, P., and Jibson, Randall W., 2002 (in press), Landslide hazard map of Tegucigalpa, Honduras: U.S. Geological Survey Open-File Report.
Servicio Metereologico Nacional, 1999, Registracion de precipitacion y temperatura: Unpublished Data.

Varnes, D. J., 1978, Slope movement types and processes, in Schuster, R. L., and Krizak, R. J., eds., LandslidesAnalysis and Control: Transportation Research Board Special Report 176, National Academy of Sciences, Washington D. C., p. 11-33. 